\title{
Culture Cullt Clan 2001: comments on the survival of Torres Strait culture
}

\author{
Janice Peacock
}

\section{Introduction}

As an Indigenous female artist of Torres Strait Islander descent, born in Mareeba, North Queensland and raised in Brisbane, my artwork addresses, often in a satirical vein, various historical themes and some misconceptions about the survival of Torres Strait culture. This is influenced by the fact that many people are unaware of how much of Torres Strait Islander traditional culture has survived, and how deeply it influences contemporary Torres Strait Islander artists' sensibility and practice.

For almost 150 years since European invasion and rule, Australia's Indigenous Torres Strait Islanders have survived occupation, attempted genocide and powerful pressures to conform to Eurocentric lifestyles. These alienate us and are devoid of what could enable us to sustain traditional links to our histories, our seas and our lands. Nonie Sharp, sociologist and chronicler of the 'hidden history' of the Torres Strait clarifies this further when she states:

Alongside the belief that Islanders had no socially relevant pre-colonial past lay a complementary assumption: that they could make no claim to an independent history since the arrival of those who took on the role of their rulers. According to that conception, the history of Torres Strait since conquest is solely one of attempts to change and 'develop' Islanders. For them history was now 'frozen': they were simply men and women conforming to a pattern of assimilation. Social reality was so constructed for them that they appeared as faceless figures in an alien world. They were not making history; it was being made for them. ${ }^{1}$

I reflect on this statement when discussing the background and formation of my art installation in this paper. The installation, entitled Culture Cullt Clan 2001, was created in response to the work of the anthropologist Roger Sandall, and his comments about the primitiveness of Indigenous cultures. According to Sandall, Indigenous cultures have nothing to offer the modern world and need to reach 'civilisation' through 'assimilation' and the 'acquisition of the rules of civil society'. ${ }^{2}$

1. Sharp 1980: 12.

2. Interview with Roger Sandall 2001, ABC Radio National. 


\section{Exchanging histories}

As an Indigenous female of Torres Strait Islander descent, born and brought up on the mainland of Australia, I am connected with, and affected by, wider Australian Indigenous issues, particularly those resulting from the alienation and dislocation stemming from colonialism. In this paper, the terms 'dislocation' and 'alienation' are applied specifically to dispossession from traditional lands, and not to the movement of nonIndigenous populations throughout the period of imperialist colonial expansion. These themes are a reflection of my own background of alienation and dislocation from my Torres Strait Islander roots and homeland.

Like many Torres Strait Islanders of my generation, I am of multi-ethnic descent: Sri Lankan, Danish, Indonesian, Irish and English. Having multiple heritages is a feature of my identity and ultimately influences how my work is perceived. My own art practice has been strongly influenced by Torres Strait Islander visual/performance artists like Destiny Deacon, Clinton Nain and Ken Thaiday Snr (all originating from Erub) and Ellen Jose, each of whom has elaborated those aspects of Indigenous identity and culture which speak most personally to them and their particular talents. Another major influence on the content and production of my artworks since 2000 has been the processes involved in Cuban born artist Coco Fusco's art performances, and her sardonic commentaries on Western concepts of the exotic and the primitive Other. ${ }^{3}$

I do not see myself as representative of Torres Strait Islander people, and my views reflect:

an individual consciousness, rather than a community consciousness, to express issues such as the search for identity and the effects of political, colonial and religious limitations [and convictions], on the lives of Torres Strait Islanders and other Indigenous people. ${ }^{4}$

My artworks interweave and juxtapose European and Torres Strait historical and cultural themes and perspectives. Discussing my work inevitably involves writing about and revisiting history as a means to explore my identity as a 21st century Torres Strait Island woman of multi-ethnic descent.

I strongly believe, based on my experience as an artist, that 'visual dialogue' is an expressive, persuasive, and often necessary, means to provide diverse ways of telling multiple histories. I also believe that the implications of contemporary historical practice and the potential these implications have to decolonise history, lie precisely in these many diverse interpretations, understandings and meanings of being 'Indigenous', for past, present and future generations.

\section{Background to the work}

The work which is the topic of this paper, Culture Cullt Clan 2001, is the response of a female urban mainland Torres Strait Islander to a persistent general belief, as expressed in the opening quote, ${ }^{5}$ that Islanders have no history. The work seeks to clarify 'old'

3. Fusco 1998: 363 .

4. Torres Strait art in transition 2005; see also Mosby 1998b: 88 .

5. Sharp 1980. 
traditions, whilst adapting to a continually changing, globalised, technologically modern, 'new' world.

The underlying assumptions that Indigenous cultures are 'primitive' and doomed to extinction ${ }^{6}$ are based on now discredited anthropological notions of 'race' and the 'racial hierarchy'. However, some contemporary scholars appear to continue to hold such views, one being the anthropologist Roger Sandall. He writes:

The division is deep - there is a Big Ditch between the tribal world and modernity. Until around 1970 governments in the United States, Canada, Australia, and New Zealand accepted this fact, and they saw their duty as helping indigenes to cross the divide. For that reason they concentrated on better health, education, and housing, and let the chips of traditional culture fall where they may. That was how Western civilisation had dealt with its own traditions, creatively destroying those that would not change. Creative destruction is the law of historical advance. $^{7}$

Culture Cullt Clan 2001 ('Cullt' as in 'Culled') was conceived and created as a pointed and playful response to Sandall's views.

Sandall's pronouncements about the 'primitive' character of Indigenous peoples first came to my notice in a newspaper article by Nicholas Rothwell. ${ }^{8}$ Sandall uses 'the big ditch' image to describe what he sees as the separation between modern democratic societies and the tribal worlds of Native Americans, Maori and Aborigines. He claims that views and proposals held by academics and anthropologists over the past 30 years belong to what he terms a 'culture cult' or 'designer tribalism'. Their views are to him 'romantic dreams running deep through the fabric of modern philosophy, social criticism and political thought', and suggests that 'you have to have an 18th century Enlightenment view and an anti-romantic temperament like his' to deal with the big ditch 'problem'.

If your traditional way of life has no alphabet, no writing, no books, and no libraries, and yet you are continually told that you have a culture which is 'rich', 'complex', and 'sophisticated', how can you realistically see your place in the scheme of things? If all such hyperbole were true, who would need books or writing? Why not hang up a 'Gone Fishing' sign and head for the beach? ${ }^{9}$

Sandall sees the current 'scheme of things' as justified by the possession and maintenance of an alphabet, books and libraries and that these are the measure of the worth of a culture/society. Those without such attributes are apparently unworthy of existence, have no place. In an interview on $A B C$ radio he discussed the term 'civilisation'. For Sandall, 'civilisation' or 'civil society' is the 'proper conduct amongst equal citizens who set aside cultural difference': he gives us, as an example, a Sydney beach being occupied peaceably by people of many nationalities. This, he suggests, is 'part of the

6. Historian Russell McGregor comments on the doomed race theory as 'neither a sop for disturbed consciences nor an empirical demographic prediction' but more than anything else 'it was a manifestation of ultimate pessimism in Aboriginal abilities' (McGregor 1997: 18). Further discussion of this follows below.

7. Sandall 2001:3.

8. Rothwell 2001.

9. Sandall 2001: 4. 
entire story of civilisation'. He concludes that, to reach 'civilisation', Indigenous peoples need to cross the divide, his 'big ditch', which separates them from the modern world. This can be done through 'assimilation' and the 'acquisition of the rules of civil society'. ${ }^{10}$

According to Sandall, governments around the world saw it as their 'duty' to help lndigenous people to cross the 'big ditch', supposedly, to 'advance' them. In my view, this attribution of 'creative destruction' is paternalistic in that it generates a philanthropic view of how 'colonisers' operated upon first 'settlement' in previously inhabited lands. Sandall's view would imply that government legistation and policies such as the White Australia Policy and assimilation were introduced to improve Indigenous well-being. 'Historical advance' in Sandall's terms, is measured by a history that denies its true origins, as has now been made clear in such reports as 'Beyond the Act' $^{\prime 11}$ which was written and researched solely by Australian Indigenous people. It indicates the failure of most written accounts to give an accurate picture of early European 'settlement' in Queensland.

John Harris, in his revisionist history of Australian missions, One Blood, argues that 'civilisation' was constructed 'as a deadly force in itself'. ${ }^{12}$ Harris gives examples of how 'civilisation' was implemented by colonisers who did their utmost to forcibly remove Indigenous inhabitants from their lands, without any remorse, concern or consideration towards them. He points out that authorities stole the land; they massacred, destroyed, and dismantled everything of value, to keep Indigenous people in jeopardy. Those who survived each bloody encounter were constituted (or 'imprisoned') as British subjects. ${ }^{13}$ Declaring war would mean recognising Aborigines as an invaded people rather than, as they were legally defined, 'British subjects', whose resistance to the British system of law became logically a 'criminal act' by 'outlaws' ${ }^{14}$

Because British civilisation was deemed to be Christian civilisation, to be 'British' was to be a 'Christian' ${ }^{15}$ and vice versa. Therefore, 'civil life' was enforced as a means to 'Christianise' Indigenous people and make them 'abhor' their origins. ${ }^{16}$ Thus, contrary to Sandall's view, rather than be 'advanced', Australia's Indigenous peoples had to struggle to 'survive' beyond the brutalities that were forced upon them by settlers and colonisers.

According to Sandall, Western civilisation operates by 'creatively destroying those that would not change'; moreover, he regards this 'creative destruction' as the law of historical 'advance'. He uses these terms because he supposes that 'primitive' societies have nothing to offer modern or 'civil' society. In the introduction to his book, he states that 'most traditional cultures feature repression, economic backwardness, endemic disease, religious fanaticism, and severe artistic constraints'. He holds certain academic and media circles - which he claims give voice to the 'culture cult' - as responsible for

\footnotetext{
10. Interview with Roger Sandall, 25 June 2001, ABC Radio National.

11. Malezer 1979.

12. Harris 1990: 70.

13. Harris 1990: 72-73.

14. Malezer 1979: 9.

15. Harris 1990: 45 .

16. Harris 1990: 44-45.
} 
promoting 'noble savage' interpretations with regards to Indigenous people, and claims that 'they (the Culture Cult) haven't a clue what they are getting themselves into'. ${ }^{17}$

From an Indigenous viewpoint, both Sandall's views and the views he opposes are flawed. Moreover, it could be argued that Westerners' attempts to identify themselves with the plight of Indigenous peoples perpetuate conflicting but equally patronising and romantic views of Sandall's 'creative destruction'. Attempting to reconcile all of these viewpoints (and thinking that Sandall, too, could not see what he was 'getting [himself] into'), I was prompted to produce the Culture Cullt Clan 2001 installation.

\section{The work itself}

The Culture Cullt Clan 2001 installation comprises four separate glass cabinets, each containing a head-dress with corresponding items. Each is accompanied by an 'anthropological' document featuring a member of my family wearing a head-dress or armband, and a metal plaque engraved with a quote from Sandall's book.

Use of these quotes does not imply that Sandall is representative of all anthropological thought and practice, but it does draw attention to the fact that in the publication of Sandall's book in 2001, with its stereotypical indigenous inferences and references, influenced by paternalistic patterns and 18th century enlightenment views, these ideas are still actively circulating today. Thus, the installation represents my satirical responses to Sandall's work.

The work is centred on 'urban identity', as shown by the title Culture Cullt Clan 2001. This references the 'fragmentation' of Indigenous societies as a consequence of imperialism and colonisation - disconnection from our languages, histories, landscapes, social relations and our very way of thinking and interacting with the world. Museums have for centuries embodied that fragmentation, which is also why I place my work within that context. ${ }^{18}$ By doing this, I seek to explore how cultural items, and the people who created them, become 'objects': the museum context ${ }^{19}$ stresses the themes of 'alienation' and 'dislocation', which are the products of 'Imperialism's dehumanising imperatives'. ${ }^{20}$

The need to consider an artefact within its cultural context, that is, within its own indigenous classificatory system, is vital for those items to retain their own cultural history and hence 'sovereignty'. So I present my culturally contemporary items within the present day relationships in which they belong, by placing them with photographs of my family members, taken in 2001, and the accompanying anthropological document with comments that respond to Sandall's quotes.

One glass cabinet in the installation series contains a 'satellite dish' head-dress, two 'scarification' armbands and a 'source stirrer' dance rattle. The satellite dish headdress represents Torres Strait Islanders' sea life and their recognition of vast star sys-

17. Sandall 2001: viii-ix.

18. Smith 2003: 28.

19. Lawrence 1994: 337.

20. Smith 2003: 26 . 


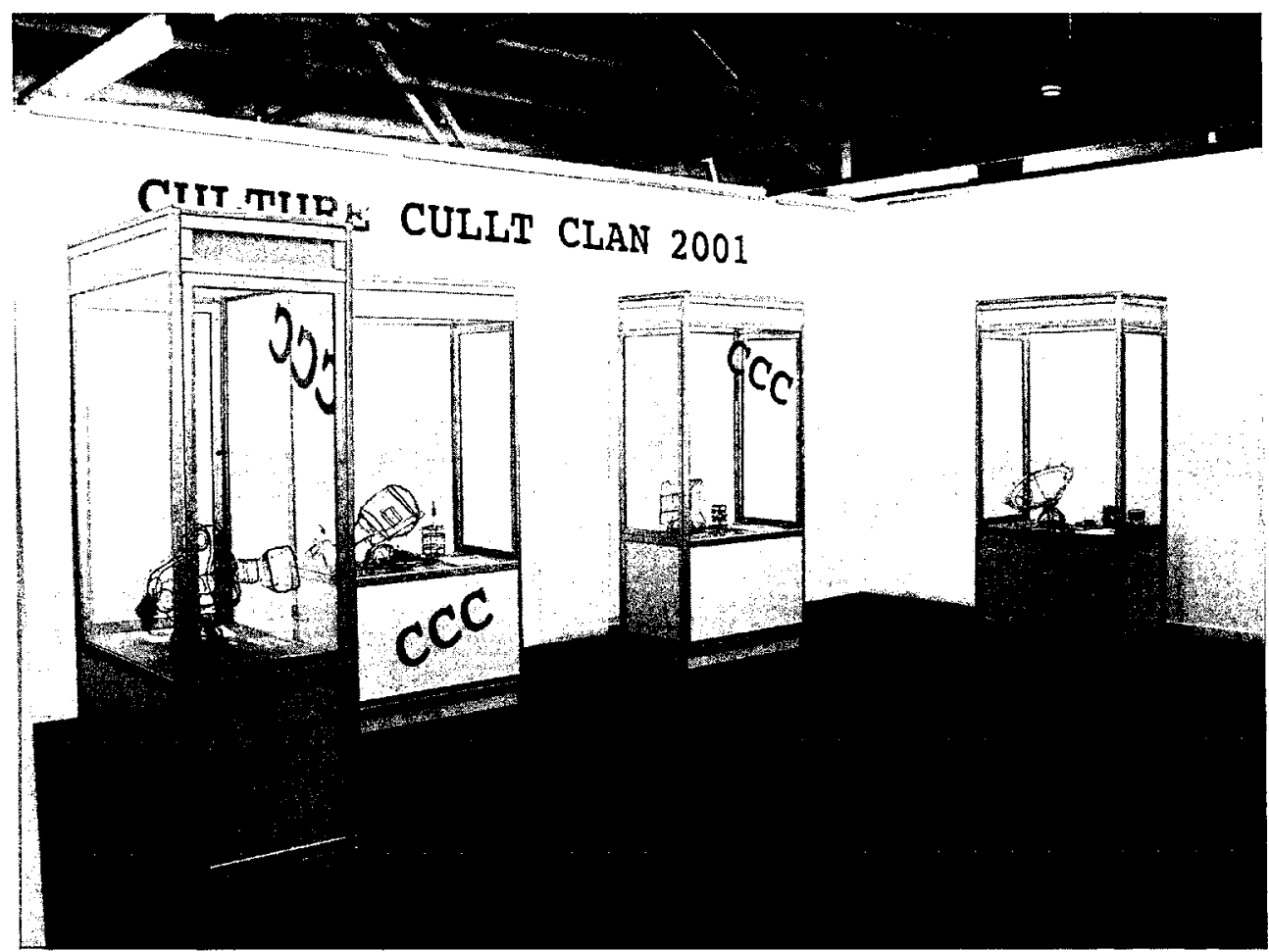

Fig 1 Culture Cullt Clan 2001 (installation). Janice Peacock 2002. In 'Six coats of Black' (Camp-fire group exhibition), Fire-works Gallery, Brisbane. Photo: Elton Cole, courtesy of the author.

Clockwise: Movie Camera series: head-dress; film cartridge; dance rattle (dimensions vary); A4 document; engraved metal plaque $10 \times 20 \mathrm{~cm}$. Gone Fishing series: head-dress; armband; dance rattle (dimensions vary); $A 4$ document; engraved metal plaque $10 \mathrm{x}$ $20 \mathrm{~cm}$.Laptop Computer series: head-dress; armband; dance rattle (dimensions vary); A4 document; engraved metal plaque $10 \times 20 \mathrm{~cm}$. Satellite Dish series: head-dress; armbands; dance rattle (dimensions vary); A4 document; engraved metal plaque $10 \times 20 \mathrm{~cm}$.

tems, which ultimately signal back to those living on the mainland in 'satellite' communities who are highly involved in the promotion of their culture. ${ }^{21}$ The spiral used in the centre of the satellite dish head-dress and accompanying armbands symbolises renewal of life, from the old to the new, and the changing of the seasons. ${ }^{22}$

I use the photograph of my mother in the accompanying 'anthropological' document, together with the words 'creative destruction: historical genocide', to give recognition to my family's history, and our alienation from our Erub (Darnley Island) connection as a result of colonial intervention. However, through the creation of my artworks, which stems from a desire to reclaim my Torres Strait Islander identity and history, 'creative destruction' is transformed into 'creative adaptation'.

21. Bani 2000: 163

22. Sharp 1993: 6 . 


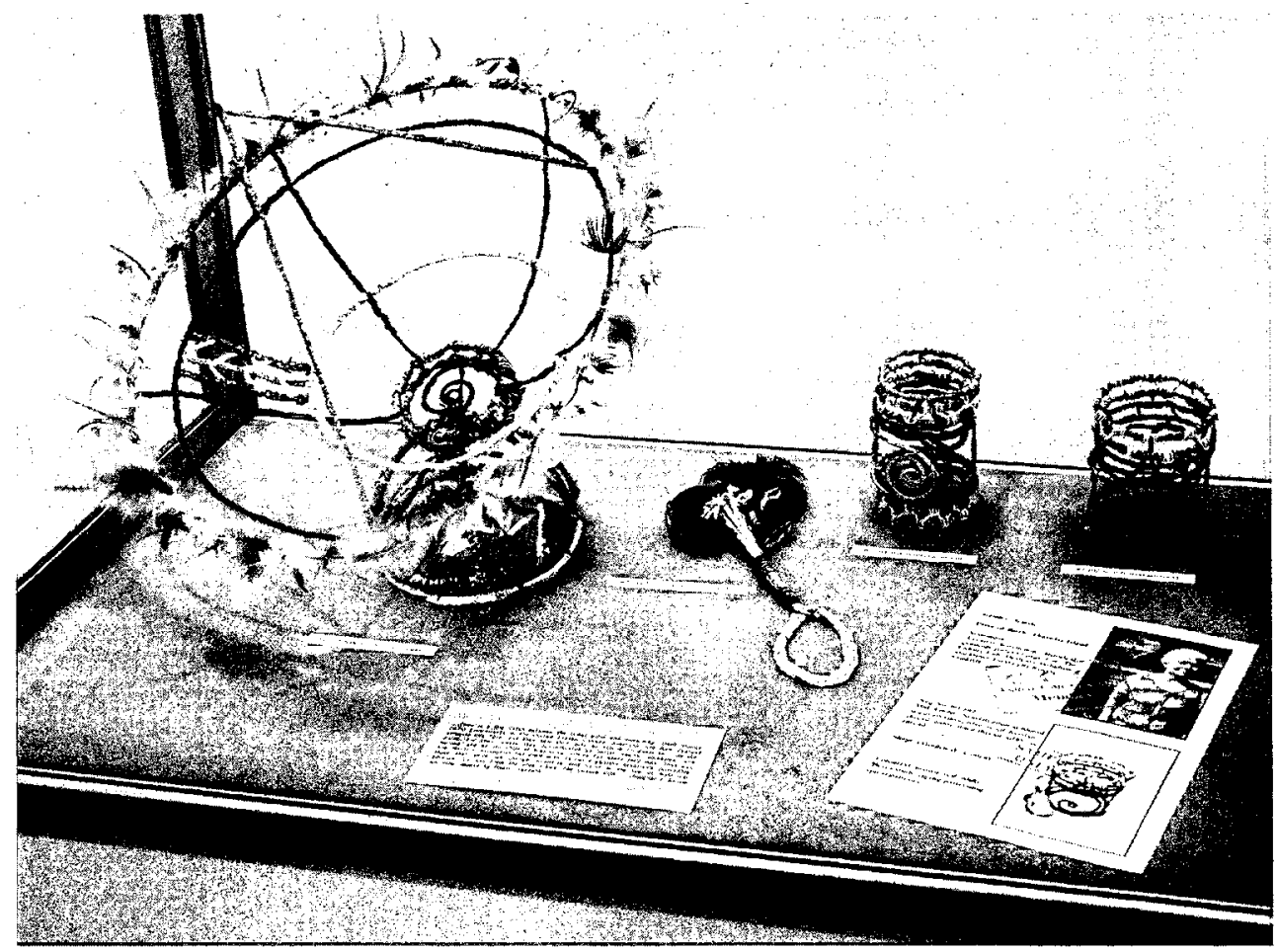

Fig 2 Satellite dish (installation component) in Culture Cullt Clan 2001. In 'Six coats of Black' (Camp-fire group exhibition), Fire-works Gallery, Brisbane. Photo: Elton Cole, courtesy of the author.

Satellite dish head-dress: wire, string, wool, feathers, seagrass, embroidery, cotton, $43 \times 50$ $x 43 \mathrm{~cm}$. Scarification armbands: wire, string, wool, seagrass, embroidery cotton, $13 \times 9 \times$ $9 \mathrm{~cm}, 10.5 \times 9.5 \times 10 \mathrm{~cm}$. Source stirrer's dance rattle: sauce stirrer, string, wool, feathers, seeds, seagrass, $33 \times 9 \times 9 \mathrm{~cm}$. Engraved metal plaque $10 \times 20 \mathrm{~cm}$; A4 size document. Janice Peacock 2002.

Hence my argument in this installation component is that the attempt by colonial government powers to destroy Australian Indigenous peoples' histories and cultures through 'creative destruction' could be termed 'historical genocide'; and that any 'historical advance' gained by Torres Strait Islanders was achieved not by white imperialist destruction but by Islanders' constant 'creative adaptation' through resistance to Western influences.

The hope was that Torres Strait Islanders would come to reflect the social makeup of the colonisers. The failure of Islanders to become replicas of those who appointed themselves to remould them baffled their rulers and interpreters alike. ${ }^{23}$ The strength to resist arose from continuity of kinship ties and a strong cultural desire to survive and 'advance' by continuing to own their identity as Torres Strait Island people. The installation series under discussion turns on its head Sandall's view that assimilation and the 'acquisition of the rules of civil society' result in societal 'advance'. 


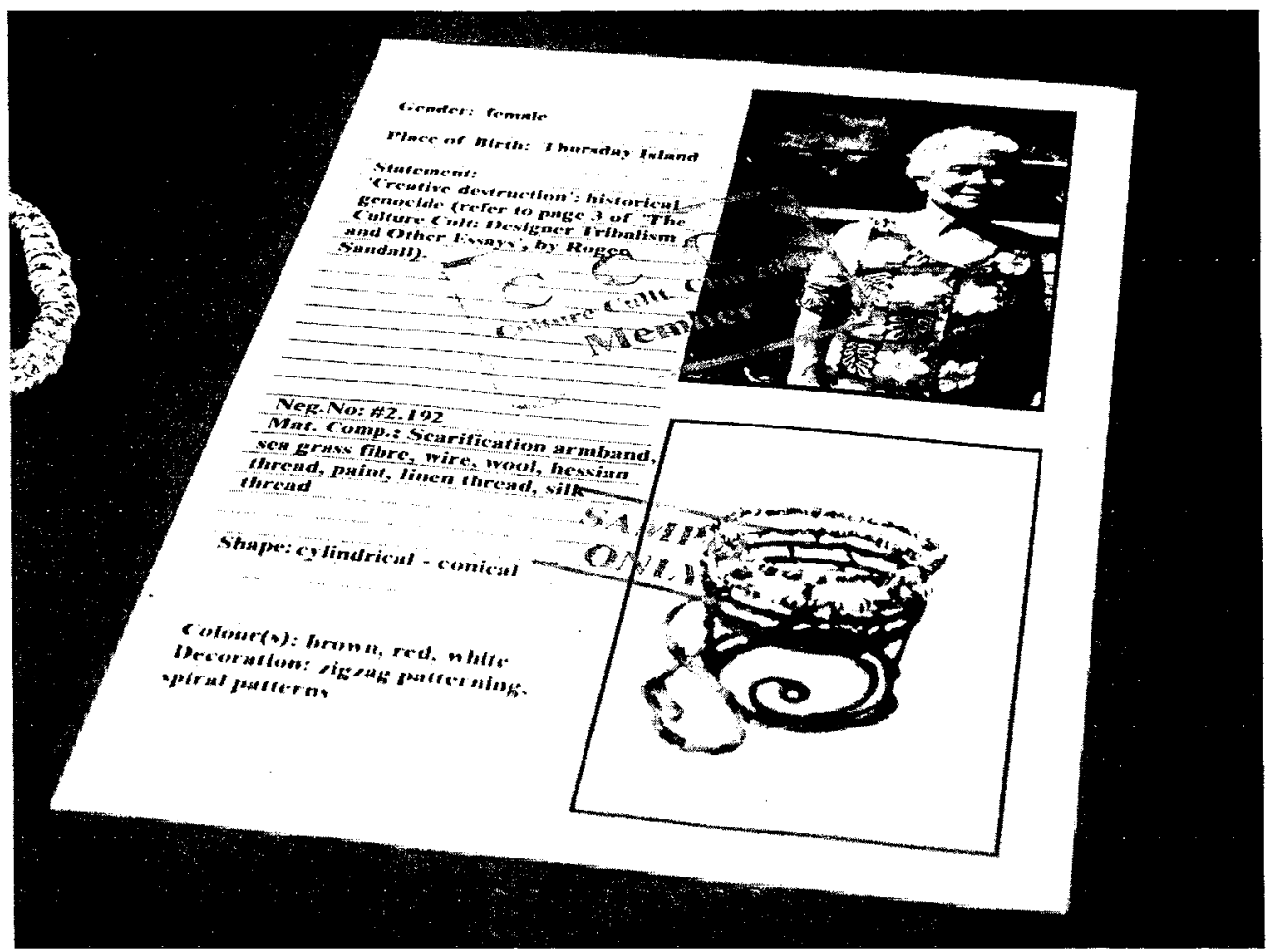

Fig 3 Creative destruction: historical genocide. Digitally enhanced A4 size document in Satellite dish series, Culture Cullt Clan 2001 (installation). Janice Peacock 2002. (Digital imaging: Jason Castro Dooley. Photo: Janice Peacock.)

In 'Six coats of Black' (Camp-fire group exhibition), Fire-works Gallery, Brisbane. Photo: Elton Cole, courtesy of the author.

Claude Levi-Strauss, a leading figure of structuralist anthropology, holds that differences between cultures 'are extremely fecund' ${ }^{24}$ He believes that 'it is only through differences that progress has been made' and that 'in order for a culture to be really itself and to produce something, the culture and its members must be convinced of their originality'. Sandall's 'simplistic' ideal of 'setting cultural difference aside' ignores or dismisses the complexities that Levi-Strauss observes, which arise when living in a modern multicultural society.

This is a view shared by many Torres Strait people. For example, Torres Strait Islander academic, Professor Martin Nakata comments on how Torres Strait Islanders have 'an intellectual capacity that is equal to others. We have cultural knowledge, tradition and history that shape our world-view and constitute not inferiority, but distinctiveness and difference'. ${ }^{25}$ And Auntie Flo Kennedy, a revered Torres Strait Island elder, is intensely aware that 'people who know their own ways can get on with other people who know theirs' ${ }^{26}$ She apprehends how the originality of our cultures

24. Levi-Strauss cited in Sharp 1993: 90.

25. Nakata 2004: 172.

26. Kennedy cited in Sharp 1993: 90. 
and, ultimately, what is 'culturally appropriate' for us, is essential to our being and our ways of relating to one another. She concludes that 'knowing who we are and where we come from is the essence of reciprocal interrelations between cultures' ${ }^{27}$ As Indigenous people, we understand that reciprocal relationships are the essential basis for living with others. Auntie Flo Kennedy's acceptance and recognition of a culturally diverse paradigm is borne out by the cultural diversity found in many contemporary Indigenous families, ${ }^{28}$ including my own. Because 'knowing who I am and where I come from' is considered within Indigenous communities to be essential for reciprocal responses to others, reclaiming my 'being' through knowing my family's ailan history is for me the first step towards an appropriate art practice.

This, however, is not without its difficulties. Torres Strait curator, Tom Mosby, in discussing categories of 'otherness' describes a scene from the science fiction television series Star Trek Deep Space Nine, in which human skin colour is a non-issue and negation of the black-white inferiority-superiority dichotomy is transformed into a human versus non-human dichotomy. ${ }^{29}$ Mosby then makes an analogy with what happens when Torres Strait Islander art is addressed within the concepts of Western art. He states that:

on the one hand, there is a concerted attempt to bring Indigenous art into the realm of the 'enlightened' Western art industry. Instead of looking at the differences, a search for affinity is attempted, in particular the search for a 'global stylistic pluralism' ${ }^{30}$

Levi-Strauss makes a related point regarding the danger of the 'over-communication of modern technology', which he fears brings with it 'the prospect of our being only consumers of other cultures' and thus 'losing all originality'. ${ }^{31}$

While acknowledging that there are a great variety of anthropological views on Indigenous societies and cultures, critiquing certain anthropological ideas and practices provides fertile material for, and is implicit within, all my artworks. Given that Western colonialist ideologies continue to distort indigenous representations, history and art, even where current attempts are made to counteract past discrepancies, my reclamation of my personal history from an Indigenous viewpoint must contest past non-acknowledgements, exclusions or misrepresentations, exemplified by Sandall's arguments.

\section{Anthropology, art and art collecting in Torres Strait}

The arrival of the London Missionary Society at Erub in 1871 was instrumental, not only in outlawing traditional customs and items of traditional worship but also in the dispersal of artefacts from the islands into overseas institutions. Between 1871 and 1910 missionaries bought and commissioned artefacts which were purchased by the British Museum, Museum für Völkerkunde, Dresden, and the Royal Museum of Scotland, Edinburgh. ${ }^{32}$ But the best-known collections of 19 th century Torres Strait material remain those made by Haddon, which were distributed to Cambridge University and

\footnotetext{
27. Kennedy cited in Sharp 1993: 90.

28. Sharp 1993: 90.

29. Mosby 1998a: 79.

30. Mosby 1998a.

31. Levi-Strauss cited in Sharp 1993: 90.

32. Herle and Philp 2000: 157.
} 
the British Museum, with smaller collections allocated to the National Museum of Ireland, Dublin, the Pitt Rivers Museum, Oxford, and the Queensland Museum, Brisbane. Haddon's own views on art are interesting in this context. The connection between European materialism and social science is pointed out by Sharp: 'Generally speaking, the societies which have moulded the consciousness of the social scientist, are those in which commodity production is universal ${ }^{\prime 33}$

So it was with the arrival in Torres Strait of AC Haddon, first in $18888^{34}$ and ten years later in 1898 as leader of the Cambridge Anthropological Expedition ${ }^{35}$ that 'the chips of [Torres Strait Islanders'] traditional culture' would consequently 'fall where

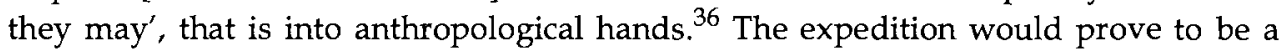
turning point in Torres Strait history and the history of British anthropology, setting a local precedent for a strange (to Islanders) scientific world of documentation, objectivity and the absolute. ${ }^{37}$

The importance of Haddon's work cannot be underestimated, in terms of his handling of the multidisciplinary team he had chosen, who devised and developed new techniques for extracting, recording and analysing the anthropological and ethnographical information they gathered. The first use of moving film in Australia as an aid to ethnographical fieldwork was Haddon's filming of a re-enactment (proposed by Haddon) of a Malo ceremonial dance by Murray Islanders in 1898 (Saunders 2001: 59). This motivated me to create a 'movie camera' head-dress, with accompanying items, in one component of the Culture Cullt Clan 2001 installation series (see fig 4).

Haddon's definition of ethnography was as 'a branch of anthropology concerned with the scientific description of a human society'. ${ }^{38}$ This did not preclude his team members from having remarkably friendly interactions with the Torres Strait Islanders. Moore states that:

Haddon was distinguished from any of his predecessors, as allying a strong belief in the importance of scientifically based field-work and possessing a deep humanity and total lack of condescension towards his fellow men. ${ }^{39}$

A certain sentimentality can be found in Haddon's 1898 diary entries: on leaving Thursday Island for what he thought would be the last time, he writes that it is as if parting from a close personal friend whom I shall never see again' ${ }^{40} \mathrm{He}$ did in fact

33. Sharp 1980: 14 .

34. Haddon was then Professor of Zoology at the Royal College of Science, Dublin. He visited the Torres Strait to study the marine biology of the reef systems there. Working mostly with the local inhabitants, he became fascinated with the people and ended up spending as much time collecting traditional artefacts as he did working on reef biology (Moore 1984: 10-11).

35. The expedition included scholars in the fields of ethnology, psychology, medicine and linguistics and also had expertise in music, art and photography. Its members spent approximately seven months in Torres Strait, with further comparative research in Cape York and New Guinea before returning to England (Herle 1998: 114). Haddon also returned to the Torres Strait in 1914.

36. Sandall 2001: 3 .

37. I use the term 'absolute' here to refer to the knowledge obtained by white occupiers, in this case by the anthropologists, being seen as the 'only' truth (Smith 1999: 67).

38. Saunders 2001: 59 .

39. Moore 1984: 12 
return in 1914, and remained in contact with his Torres Strait Islander friends for the remainder of his life. In similar vein, the Islanders whom Haddon studied and befriended displayed their own 'deep humanity' by their reciprocal response and respect for him.

However, in accordance with previous discussion to do with anthropological exploration, Sharp observes that since colonial invasion and settlement, the 'right' of the social scientist to study the people of pre-modern societies remained part of an unbalanced power situation. She states that:

it is usually inconceivable that the object of study will be free to say 'no'. Where his or her work is tied to a form of policy science whereby the social scientist acting as social engineer chooses a set of procedures in order to determine the instrumentally best course of action necessary to implement a decision, the consequences are likely to be fateful for the society which is studied. For the decisions to be made are part of the unfolding of that reality which has been created for the objects of study. Under these conditions a so-called value-free study becomes continuous and enmeshed with the social situation of capture and control. $^{41}$

An accomplice in this process is perhaps Westerners' obsession with collecting authentic objects to be preserved for the future, and is tied up with nationalist politics and national identity formation. ${ }^{42}$ Whilst this ensured the preservation of objects for over 100 years, it also ensured their disconnection from the communities that created them. Hence the vast documentation of Islanders' traditional life and customs and the over 1,000 artefacts collected by the Cambridge Anthropological Expedition served as evidence of Westerners' 'historical advance' over 'primitive' races. ${ }^{43}$

One result was the six-volume Reports of the Cambridge Anthropological Expedition to the Torres Straits. ${ }^{44}$ A descriptive catalogue of the artefacts collected, published by David Moore in 1984, has since made previously unphotographed and inaccessible material available to Torres Strait Islanders themselves. Moore noted that Islanders were atternpting to reconstruct their own culture in order to clarify and consolidate their identity as a people. ${ }^{45}$ Another source of Islander traditional and contemporary art is the extensive catalogue of Torres Strait Islander traditional and contemporary artworks from the first major Torres Strait art exhibition, Ilan Pasin (this is our way): Torres Strait Art (1998) which also contained major artefacts from the Cambridge Collection.

So it can be said that items of material culture (sometimes gained exploitatively) ${ }^{46}$ were taken away from Torres Strait to become part of the education system of imperialist European societies; and not shared with Islanders. This past restriction on access by Torres Strait Islanders to these records and artefacts ${ }^{47}$ could also be seen as part of the

40. Haddon cited in Moore 1984: 12.

41. Sharp 1980: 16.

42. Stocking 1985: 238.

43. Herle and Philp 2000: 157

44. Haddon 1901-1935.

45. Moore 1984: 7.

46. For an example of an incident involving a member of the anthropological team and the unwilling surrender of an artefact by a Torres Strait Islander, see Haddon 1901: 34. 

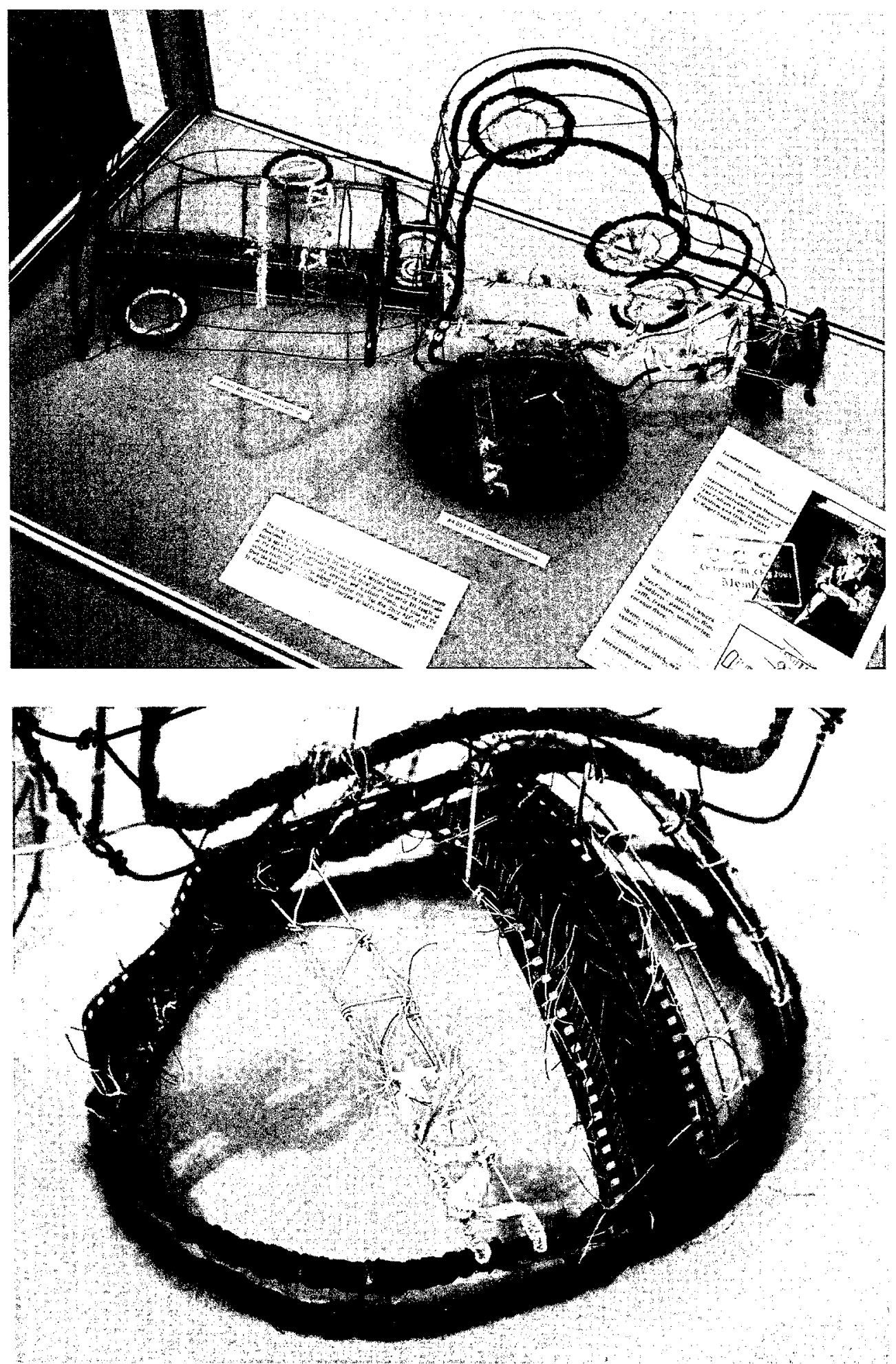


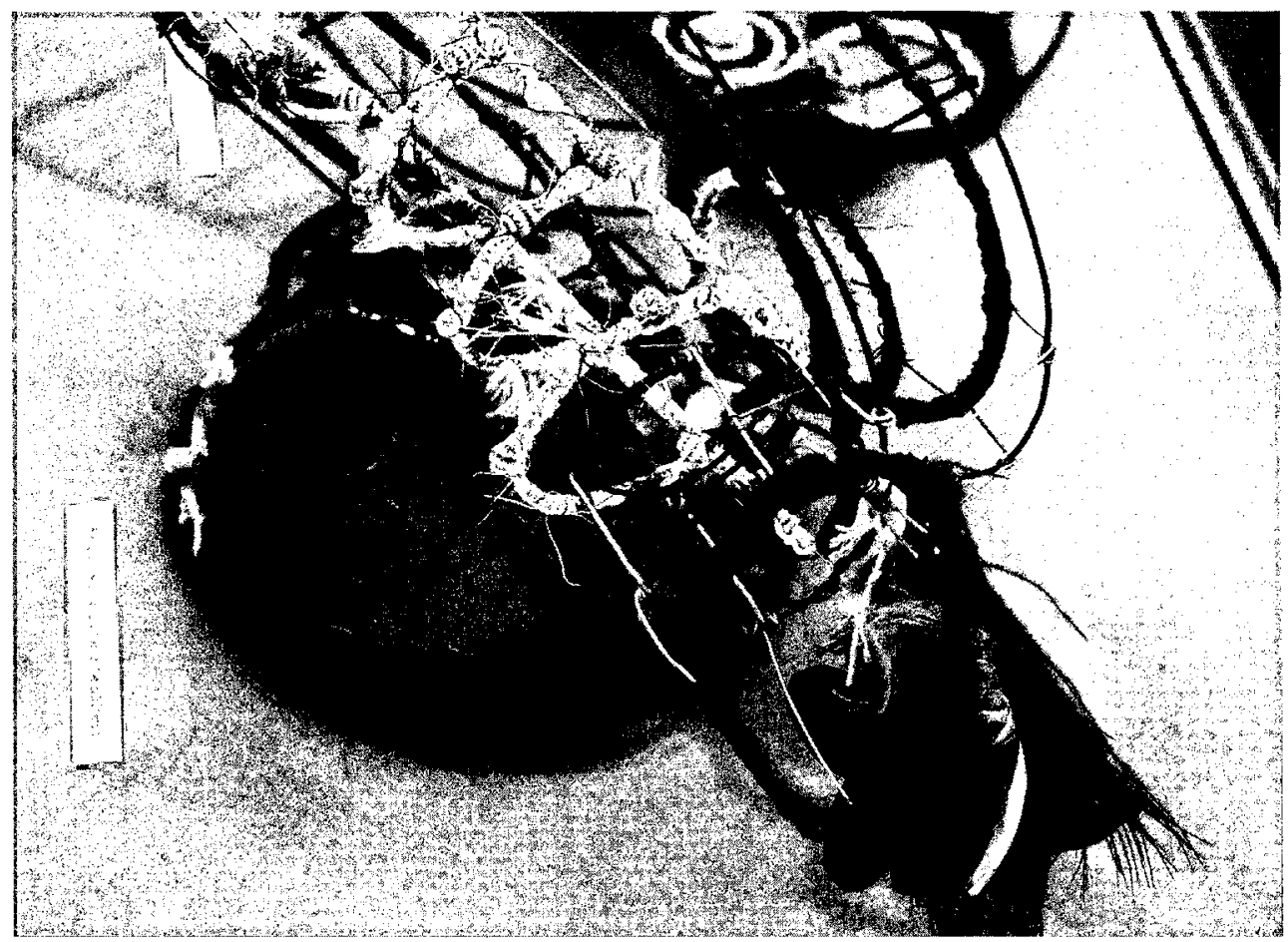

Above and previous page. Fig 4 Movie Camera head-dress (installation component) in Culture Cullt Clan 2001: head-dress; film cartridge; dance rattle (dimensions vary), wire, string, paint, seagrass, raffia, shells, feathers, seeds, film, A4 document, engraved metal plaque $10 \times 20 \mathrm{~cm}$. Janice Peacock 2002. In 'Six coats of Black' (Camp-fire group exhibition); Fire-works Gallery, Brisbane. Photo: Elton Cole, courtesy of the author.

project of 'creative destruction', or, more accurately, 'historical genocide', that brought a new and different kind of law and order to Islanders in order to further the West's own 'historical advance'. However, it is through records obtained from these major collections that contemporary Torres Strait Islanders have had access to traditional items and information today. ${ }^{48}$ I myself drew upon the Haddon archival collections for inspiration in the production of my artworks, in particular those for Culture Cullt Clan 2001.

My great-grandfather, Thomas Randolph, who met Haddon in 1888,49 was part of that colonial history. Their meeting demonstrates in a small way the diversity of relationships and encounters within 'historical colonialism' and illustrates how Torres Strait historical events are juxtaposed with our own personal histories. I am reminded of Auntie Flo Kennedy's words concerning the acceptance of cultural diversity and the importance of 'knowing who we are and where we come from'.

47. See Fuary 1998: 123; McGrath 1998: 104.

48. See Fuary 2000: 124.

49. See Haddon 1901: 176. 
This inevitably raises the question of what would have happened if Haddon and his anthropological team had not extensively collected and documented those artefacts. Today's Torres Strait Islanders can be thankful that many artefacts were preserved, even more so since negotiations began for them to be returned to the Torres Strait. ${ }^{50}$

Serious negotiations for the artefacts to be returned to Torres Strait and their owners have been held since 1998, the year of the exhibition, Ilan Pasin (this is our way). ${ }^{51} \mathrm{~A}$ previous attempt to regain cultural items is recorded in the documentary film made by Frances Calvert in 1997, Cracks in the Mask. Ephraim Bani, a Mabuiag man from the western islands, travelled to Europe with his wife in the hope of bringing artefacts back to those families whose ancestors had made them, including their own. His efforts at the time were in vain but, with the opening of the Gab Titui Cultural Centre on Thursday Island in 2004, the return of items to Torres Strait Islanders is now within sight. ${ }^{52}$ The centre is the result of intense negotiation over recent years to establish a muchneeded cultural centre in the Torres Strait and it is the first public keeping place for historical and cultural artefacts and art, both modern and traditional. It was hoped that the new centre could be an incentive for Cambridge University and other museums to restore items to Torres Strait Islander people. ${ }^{53}$

In 2002, an exhibition entitled Past Time: Torres Strait Islander Material from the Haddon Collection, 1888-1905 exhibited 60 artefacts at the National Museum of Australia, Canberra. This was the first time artefacts from the Haddon collections had been returned to Australia since their original collection. They later toured to Cairns Regional Gallery from June to September of the same year. Terry Waia, then chairman of the Torres Strait Regional Authority, clarified how extremely important these artefacts are to Torres Strait Islanders as they represent our ancestors, our identity, who we are and where we come from as a people (Waia n.d.). Torres Strait Islander artist, Victor McGrath, ${ }^{54}$ refers to his respect for the nameless makers of 'the rare and beautiful Torres Strait treasures' he was privileged to be able to view and handle, which were taken away and housed in museums in Britain and the United States. Fuary similarly refers to Yam Islanders' feelings of not having had access to past photographs and objects and their responses when given the opportunity to do so. ${ }^{55}$

I have further concerns about how the continued possession of artefact collections is weighted more towards satisfying a possessive Western 'self' ${ }^{56}$ According to Aboriginal artist, Ron Hurley, the purpose of museum ethnographic collecting was:

50. The Cape York Aboriginal collections of WC Roth, the Northern Protector of Aborigines at that time, are the only other Australian Indigenous collections, which can compare to Haddon's in scope and documentation. These two collections are amongst the most complete and fully documented amongst indigenous peoples in any part of the world (Moore 1984:39).

51. Bani 1998: 127-130.

52. The expression gab titui 'journey of the stars' combines words from both eastern and western languages of the Torres Strait. The Cultural Centre was officially opened on 16 April 2004 (Armistead and Southey n.d.).

53. Bani 1998: 132.

54. McGrath 1998: 104.

55. Fuary 1998: 123.

56. Stocking 1985: 238. 
to satisfy a morbid curiosity, and an insatiable hunger for things exotic (the noble savage syndrome). These vast public and private collections of plunder sat in musty museums, juxtaposed against white man's technology and cultural icons, in order to demonstrate the order of man, the superiority of the colonisers. ${ }^{57}$

Further concerns lie with whether the Haddon Collection has been transformed to comply with Westerners' desire for 'meaning' and 'possession'. Both traditional and contemporary cultural artefacts and collections continue to be motivated by the same act of possession; by being selected, ordered, and classified in hierarchies - to become a 'good' collection, thereby betraying its origins in the reciprocal belief systems and cultural lore of the peoples the artefacts are extracted (or bought) from. Cultural objects continue to be viewed as 'personal treasures' and are portrayed as representative of our 'authenticated' cultural survival, made public according to Western art concepts. Consequently, I agree with Stocking that, when artefacts are placed in a modern museum or art gallery, a distorted 'meaning' is created by virtue of their isolation from their traditional context and this destroys their true social and cultural relations. ${ }^{58}$

The colonial principle of 'order' is perpetuated in the activities of Western science, encoded and legitimised through imperialist practices. Hence, the systematic documentation of indigenous societies can be found as bones, mummies and skulls placed in museums for public viewing and 'consumption'; given monetary value and immortalised by art galleries and private collectors; as languages to linguists; as customs to anthropologists and ethnographers; and as spiritual beliefs and behaviours to psychologists. The 'fragmentation' of indigenous societies is not purely a modern-day phenomenon, but the consequence of imperialist rule and its dedication to appropriating indigenous societies' lifestyles to satisfy its own possessive 'self'. ${ }^{59}$

Amongst these were original ethnographic 'performance' exhibitions, depicting 'primitive' people performing 'ritualistic' or 'animalistic' tasks, which spawned misrepresentations of cultural identity, thus ultimately denying the right of Indigenous people to be considered 'human'. The 'aborigines' put on displays that served to prove that European civilisation was superior; and scientific rationalisation justified paternalistic governance of indigenous peoples. ${ }^{60}$ Lynette Russell gives numerous examples of captured Australian Aboriginal people, presupposed to be 'extremely primitive and savage', who were displayed in many American freak shows. ${ }^{61}$ Their audience was told they were 'distorted in human form', and their capture and containment considered a tribute to the skills of the sideshow organisers. This also recalls the indignities suffered by Australian Indigenous women and men who were removed and transformed into show-people as a part of the larger process of 'emptying the land' ${ }^{62}$

57. Hurley 2002. Ron Hurley's work as an artist explores the alienation of living as an urban Aboriginal 'between both cultures', and makes powerful statements about the politics of dispossession (Demozay 2001: 102).

59. Smith 2003: 27-28.

60. Fusco 1995: 41-43.

61. Russell 2001: 67.

62. Poignant 2004: 39 . 


\section{Conclusion}

Coco Fusco's sardonic commentary in her art performances such as Two Undiscovered Amerindians Visit Buenos Aires ${ }^{63}$ references imperialist practices and the fragmentation of indigenous societies. It influences my work in its relation to contemporary cultural identity, and the use of 'intercultural performance' in the past as a form of public 'education' that contributed to the 'noble savage' syndrome. ${ }^{64}$

We are all affected by our personal histories and the socio-political and historical context in which they are formed. In exchanging our histories, we may privilege any one of the senses. Representing history from a visual artist's point of view provides an effective way of exchanging histories. Privileging the visual, which is arguably the most influential and pervasive medium of communication today, provides a perspective that other media, including written texts, may lack. Through my artworks, such as the Culture Cullt Clan 2001 series, I explore, express, comment on and seek audience response to my own diverse meanings regarding social identities and my own socio-cultural circumstances. Culture Cullt Clan 2001 seeks an exchange of histories, which counter any neo-colonialist capacity to exclude Indigenous historical perspectives and commentary regarding 'primitivist' views. My story-telling preference has always been the visual: I use visual means to interpret my own personal and extended family history, which I offer to my audience to interpret or translate in their own terms.

\section{Acknowledgements}

This paper is based on a chapter of my exegesis for a Doctor of Visual Art (awarded April 2006), Queensland College of Art, Griffith University. I wish to acknowledge the help and support of my family in the creation of my artworks and also my exegesis supervisors, Pat Hoffie and Anna Haebich. I owe a special debt of gratitude to Anna Shnukal for her advice and editing. Three components of Culture Cullt Clan 2001 installation series were chosen as exhibits in the Kate Challis RAKA National Indigenous Art Award, Ian Potter Museum of Art, University of Melbourne in 2003. The Gone Fishing component was a finalist in the Telstra National Aboriginal and Torres Strait Islander Art Award of the same year.

\section{References}

Armistead, S and J Southey (n.d.), Torres Strait celebrates opening of first cultural centre Qld. Media statement, Accessed 21 April 2004, http:// statements.cabinet.qld.gov.au/subscribe $/ \mathrm{html}$

Bani, M 1998, 'Torres Strait Islander collections in Australian and overseas museums', in T Mosby and B Robinson (eds), Ilan Pasin (this is our way): Torres Strait art (exhibition catalogue), Cairns Regional Gallery, Cairns: 127-132.

Bani, M 2000, 'Connections to the past', in S Kleinert and M Neale (eds), The Oxford companion to Aboriginal art and culture, Oxford University Press, Melbourne: 162-165.

Demozay, M (Compiler) 2001, Gatherings: contemporary Aboriginal and Torres Strait Islander art from Queensland Australia, Keeaira Press, Southport, Qld.

\footnotetext{
63. Fusco 1998: 366.

64. Fusco 1998: 367.
} 
Fuary, M 1998, 'Thinking Cairns and Cambridge: some aspects of the relationship between anthropology and the Torres Strait', in T Mosby and B Robinson (eds), Ilan Pasin (this is our way): Torres Strait art (exhibition catalogue), Cairns Regional Gallery, Cairns: 121-125.

Fusco, C 1995, English is broken here: notes on cultural fusion in the Americas, The New Press, New York City.

— 1998, 'The other history of intercultural performance', in N Mirzoeff (ed), Visual culture reader, Routledge, London: 363-367.

Griffiths, T 1996, Hunters and collectors: the antiquarian imagination in Australia, Press Syndicate of the University of Cambridge, Cambridge.

Haddon, AC 1901, Head-hunters black, white, and brown, Methuen \& Co, London.

— 1901-1935, Reports of the Cambridge Anthropological Expedition to Torres Straits

(Vols 1-6), Cambridge University Press, Cambridge.

Haller, JS Jr 1970, Outcasts of evolution: scientific attitudes of racial inferiority, 1859-1900,

University of Illinois Press, Chicago.

Harris, J 1990, One blood: 200 years of Aboriginal encounter with Christianity: a story of hope, Albatross Books Pty Ltd, Sutherland.

Herle, A 1998, 'Art and custom: Torres Strait objects collected by Alfred Haddon 18881914', in T Mosby and B Robinson (eds), Ilan Pasin (this is our way): Torres Strait art (exhibition catalogue), Cairns Regional Gallery, Cairns: 113-119.

Herle, A and J Philp 2000, 'Custom and creativity: nineteenth century collections of Torres Strait art', in S Kleinert and M Neale (eds), The Oxford companion to Aboriginal art and culture, Oxford University Press, South Melbourne: 155-162.

Hurley, Ron 2002, Eulogy for Ron Hurley, Unpublished pamphlet. Copy held by author. Lawrence, D 1994, 'Customary exchange across Torres Strait', Memoirs of the Queensland Museum 34 (2): 241-446.

Malezer, L, M Foley and P Richards 1979, Beyond the Act, F.A.I.R.A. (Foundation for Aboriginal and Islander Research Action Limited). Brisbane

McGrath, V 1998, 'Contemporary Torres Strait arts - an overview', in T Mosby and B Robinson (eds), Ilan Pasin (this is our way): Torres Strait art (exhibition catalogue), Cairns Regional Gallery, Cairns: 101-110.

McGregor, R 1997, Imagined destinies: Aboriginal Australians and the doomed race theory, 1880-1939. Melbourne: Melbourne University Press.

Moore, D 1884, The Torres Strait collections of AC Haddon: a descriptive catalogue, British Museum Publications Limited, London.

Mosby, T 1998a, 'Art is an act of bringing truth into being', in T Mosby and B Robinson (eds), Ilan Pasin (this is our way): Torres Strait art (exhibition catalogue), Cairns Regional Gallery, Cairns: 73-85.

— 1998b, 'Torres Strait Islander art and artists', in T Mosby and B Robinson (eds), Ilan Pasin (this is our way): Torres Strait art (exhibition catalogue), Cairns Regional Gallery, Cairns: 87-99.

Nakata, M 2004, 'Commonsense, colonialism and government', in R Davis (ed), Woven histories, dancing lives, Aboriginal Studies Press, Canberra: 154-173. 
Poignant, R 2004, Professional savages: captive lives and western spectacle, University of New South Wales Press, Sydney.

Rothwell, N 2001, 'Noble rot', The Weekend Australian April 14-15, Inquirer: 25.

Russell, L 2001, Savage imaginings: historical and contemporary constructions of Australian Aboriginalities, Australian Scholarly Publishing Pty Ltd, Melbourne.

Sandall, R 2001, The culture cult designer tribalism and other essays, Westview Press, Oxford.

Saunders, W 2001, Aboriginal Australia and the Torres Strait Islands, Lonely Planet Publications, Melbourne.

Sharp, N 1976, Millenarian movements: their meaning in Melanesia, Working Paper No. 25, La Trobe University Department of Sociology, School of Social Sciences, Bundoora, Victoria.

- 1980, 'Theme for an overview', in N Sharp, Torres Strait Islands 1879-1979: themes of continuity and change, Working Papers in Sociology, La Trobe University Department of Sociology, School of Social Sciences, Bundoora, Victoria.

— 1993, Stars of Tagai: the Torres Strait Islanders, Aboriginal Studies Press, Canberra.

Smith, TL 2003 [1999], Decolonizing methodologies: research and indigenous people 6th edition, University of Otago Press, Dunedin, New Zealand.

Stocking, GW (ed) 1985, Objects and others: essays on museums and material culture, The University of Wisconsin Press, Wisconsin.

Torres Strait Art in Transition 2005, in Ilan Pasin (this is our way): Torres Strait Art, Accessed 23 June 2005, www.cairnsregionalgallery.com.au/ianpasin/Torres.html

Waia, Terry (n.d.), Media Archives, Accessed 20 August 2002, http://www.tsra.gov.au

\section{Films}

Calvert, F (Producer), 1997, Cracks in the mask, Ronin Films, Canberra.

\section{Interviews}

Interview with Roger Sandall on 'Life Matters', 25 June 2001, ABC Radio National. 